Nepal Agric. Res. J. Vol. 9, 2009

\title{
Controlling Foliar Blight of Wheat through Nutrient Management and Varietal Selection
}

\author{
Yuba R. Kandel ${ }^{1}$ and Jaya P. Mahato ${ }^{2}$ \\ ${ }^{1}$ Plant Pathology Division, Khumaltar, Lalitpur, Nepal $<$ kandel_yr@hotmail.com $>$ \\ ${ }^{2}$ Regional Agriculture Research Station, Tarahara, Sunsari, Nepal
}

\begin{abstract}
Helminthosporium leaf blight, a complex of spot blotch caused by Bipolaris sorokiniana and tan spot caused by Pyrenophora tritici-repentis, is one of the most important foliar diseases of wheat in Nepal. It appears in almost all wheat growing areas and causes severe yield loss every year. A study was conducted at Regional Agriculture Research Station (RARS), Tarahara, Sunsari during 2004-05 and 2005-06 wheat growing seasons to elucidate role of nitrogen in wheat genotypes for management of the disease. Field experiment was laid out on split plot design with three replications. Four doses of nitrogen in six different promising genotypes were tested. Nitrogen levels higher than $50 \mathrm{~kg} \mathrm{ha}^{-1}$ significantly reduced disease severity and increased grain yield in all genotypes but there was no significant differences in grain yield in the first year. In the second year, grain yield difference among the genotypes was significant. Area under disease progress curve (AUDPC) was not significant between two doses 100 and $150 \mathrm{~kg} \mathrm{ha}^{-1}$. The wheat genotypes showed different reactions to disease. Genotype BL 2047 had the lowest incidence of disease followed by BL 1887, whereas BL 2217 had the highest incidence of the disease. Genotype BL 2196 produced the highest grain yield $\left(2172 \mathrm{~kg} \mathrm{ha}^{-1}\right)$ and the lowest grain yield was obtained in Bhrikuti followed by BL 2089. These results suggested that fertilizer should be applied in soil at balanced dose 100:50:50 N: $\mathrm{P}_{2} \mathrm{O}_{5}: \mathrm{K}_{2} \mathrm{O} \mathrm{kg} \mathrm{ha}^{-1}$. Growing relatively resistant genotypes with the balance dose of fertilizers can reduce foliar blight severity in wheat.
\end{abstract}

Key words: AUDPC, Bipolaris sorokiniana, disease resistance, grain yield, Helminthosporium leaf blight, Pyrenophora tritici-repentis

\section{INTRODUCTION}

Wheat occupies the third position after rice and maize in Nepal representing $22 \%$ of total cultivated area. Major area of wheat production is covered by eastern terai region of Nepal. Successful production for wheat is constrained by several biotic and abiotic stresses. Among them, Helminthosporium leaf blight (HLB), a complex foliar disease of wheat caused by Bipolaris sorokiniana (Sacc.) Shoem. and Pyrenophora tritici-repentis (Died) is a serious constraint. It is considered a disease of major importance owing to its potential to cause yield loss. Globally an 
estimation of 25 million ha of wheat land is affected by the disease (van Ginkel and Rajaram, 1998). In Nepal the disease is widely distributed throughout the wheat growing areas particularly in terai (NWDP 1976). The magnitude of yield loss due to HLB may vary among locations and years (Mahto 1995). In South Asia, yield loss due to HLB has been reported to to $20-30 \%$ in farmers' field and experiment stations (Dubin amd Bimb 1991, Duveiller and Gilchrist 1994, Saari 1998, Duveiller et al 2005). In years when rain occurs late in the crop cycle, especially during grain filling, complete crop loss has been observed (Saunders 1988). Selection and breeding for resistant cultivars is the main disease management strategy for a sustainable agriculture. Duveiller and Gilchrist (1994) and Dubin and Rajaram (1996) reported several sources of spot blotch resistance in wheat but high yielding genotypes resistant to the disease is not yet available. Most of the improved and recommended wheat cultivars in Nepal are severely attacked by foliar blight (Shrestha et al 1998).

Crop management practices affect on the development of the disease epidemics. In the humid subtropics of South Asia, there is evidence of stress conditions, which favor foliar blight (Dubin and Bimb 1994). Factors such as minimum tillage or surface seeding, irrigation, late planting, or low soil fertility may be responsible for higher foliar blight severity in the wheat-based cropping systems of the Indo-Gangetic plains (Sharma and Duveiller 2003). Lower disease severity with higher nitrogen application was reported by Chaurasia and Duveiller (2006) and Sharma and Duveiller (2004). However, Singh et al (1998) reported more disease infection on higher nitrogen application.

The objective of the present study was to find out the influence of nitrogen in different wheat genotypes on the severity of foliar blight.

\section{MATERIALS AND METHODS}

A split plot experiment with three replications was conducted at Regional Agriculture Research station, Tarahara Sunsari, Nepal during wheat season of 2004-05 and 2005-06 where climatic and agro-ecological conditions favor rapid development of foliar blight pathogens. The main plot treatments were four levels of nitrogen: i) 0:50:50 N: $\mathrm{P}_{2} \mathrm{O}_{5}: \mathrm{K}_{2} \mathrm{O} \mathrm{kg} \mathrm{ha}{ }^{-1}$, ii) $50: 50: 50 \mathrm{~N}: \mathrm{P}_{2} \mathrm{O}_{5}: \mathrm{K}_{2} \mathrm{O} \mathrm{kg}$

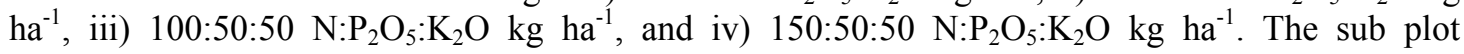
treatments included most promising wheat genotypes: BL 2047, BL2089, BL2196, BL 2217, Gautam, and Bhrikuti. The individual plot size was $4-\times 3-\mathrm{m}$ and consisted of twelve rows with $25 \mathrm{~cm}$ spacing. Seed was sown using standard seed rate of $120 \mathrm{~kg} \mathrm{ha}^{-1}$. Phosphorus and potassium were applied as basal dose. Half of $\mathrm{N}$ (for all three levels) was applied at basal dose and remaining half was top-dressed at tillering stage. Three irrigations were given. Plots were kept free from weeds by hand weeding. Daily rainfall, max and min temperature during wheat growing seasons were recorded from wheat emergence to harvest in the two test years.

After anthesis, the peak stage of disease development, disease severity was assessed using the double-digit scale (00-99) developed as a modification of Saari and Prescott's scale for assessing severity of foliar diseases of wheat (Saari and Prescott 1975, Eyal et al 1987). The first digit (D1) indicates disease progress in canopy height from the ground level and second digit (D2) refers to severity measured based on diseased leaf area. Both D1 and D2 are scored on a scale of 1 to 9 . Three individual disease scores per plot were recorded at every 7-days interval. For each evaluation, percent disease severity was estimated using the formula: \% severity $=(D 1 / 9) \times(D 2 / 9) \times 100$. The area under disease progress curve (AUDPC) was calculated using the percentage disease severity estimations corresponding to the three ratings as outlined by Shaner and Finney (1977).

Yield (kg/ha) and 1000-grain weight were measured after harvesting all plots. The data were analyzed using computer software MSTATC and MINITAB 11 for windows. Statistical analysis 
includes ANOVA test, mean separation based on Duncan's multiple range test, regression analysis for AUDPC and the grain yield over different levels of nitrogen.

\section{RESULTS AND DISCUSSION}

\section{Weather conditions and disease severity}

There was high pressure of disease in both years. However, the disease severity was significantly higher $(\mathrm{p}<0.05)$ in the second year (Table 1$)$. The difference in the disease might be due to climatic variations in these two years (Figure 1). Higher temperature in early stage of the crop cycle was observed in the second year. This result suggested the influence of temperature on disease development. Naitao and Yousan (1998) reported that Bipolaris sorokiniana resistance traits in wheat are polygenic and greatly affected by climatic factors such as rainfall, humidity and temperature. Similarly, Gilbert et al (1998) reported that humid environment resulting from high temperature and high rainfall promoted the development of the disease.

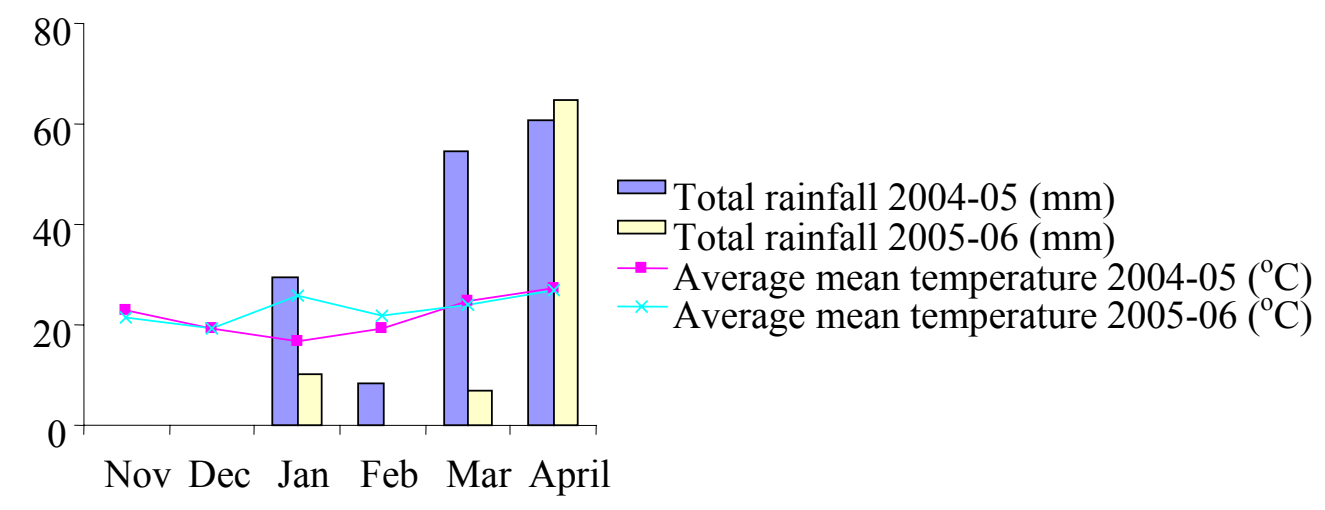

Figure 1. Monthly average climatic variables recorded throughout the wheat growing season 2004-05 and 2005-06 at Tarahara, Sunsari, Nepal.

\section{Influence of nitrogen $(\mathrm{N})$ levels on disease severity and wheat yield}

$\mathrm{N}$ levels had a significant effect $(\mathrm{p}<0.01)$ on AUDPC in both years (Table 1). Among four levels of $\mathrm{N}$ tested, the mean AUDPC value was higher for $\mathrm{N}$ levels 0 and $50 \mathrm{~kg} \mathrm{ha}^{-1}$ as compared to $100 \mathrm{~kg}$ $\mathrm{ha}^{-1}$ and $150 \mathrm{~kg} \mathrm{ha}^{-1}$. Such variation in mean values for disease severity among the four levels of $\mathrm{N}$ confirmed its role in reducing foliar blight infection in wheat. Regression analysis showed a significant negative linear relation of AUDPC, $\mathrm{Y}=657.458-6.7583 \mathrm{X}, \mathrm{R}-\mathrm{Sq}=0.048^{* *}$ over dose of nitrogen application $(0-150 \mathrm{~kg} / \mathrm{ha}$; Figure $2 \mathrm{~A})$. This result indicated that foliar blight severity was lowered with increased dose of $\mathrm{N}$.

Mean values for grain yield differed in the test years. Average grain yield was lower in 2005 than in 2004. The lower yield with more disease in the second year suggested the effect of the disease in wheat yield reductions. The effect of $\mathrm{N}$ level was significant for grain yield and thousand kernel weight (TKW) in both the years. The mean grain yield was high for $\mathrm{N}$ levels of 100 and $150 \mathrm{~kg} \mathrm{ha}^{-1}$ as compared with 0 and $50 \mathrm{~kg} \mathrm{ha}^{-1}$ but the difference between the first two levels was insignificant (Table 1). Similarly AUDPC value was also not significantly different between these two N levels $\left(100\right.$ and $\left.150 \mathrm{~kg} \mathrm{ha}^{-1}\right)$. Regression analysis showed that grain yield was increased as a function of nitrogen level, $\mathrm{Y}=521.168+716.125 \mathrm{X}, \mathrm{R}-\mathrm{Sq}=0.667^{* *}$ (Figure 2). There was sharp100 and 150 $\mathrm{kg} \mathrm{ha}^{-1}$ ) increment of grain yield over $\mathrm{N}$ application up to the dose $100 \mathrm{~kg} \mathrm{ha}^{-1}$ in all the genotypes 
but after the level, the rate of increment decreased (Figure 3). This result suggested that nitrogen level more than $100 \mathrm{~kg} \mathrm{ha}^{-1}$ was not significantly effective to lower the disease severity and to increase the grain yield. There was no specific trend for TKW over $\mathrm{N}$ levels but average value was the lowest in $150 \mathrm{~kg} \mathrm{ha}^{-1}$.

The results suggested that $\mathrm{N}$ levels had a significant influence on foliar blight development, grain yield and TKW. It was observed that low and imbalance use of nitrogenous fertilizer increased severity of the disease. Krupinsky et al (1998) noted more leaf necrosis and chlorosis caused by Pyrenophora tritici-repentis in the plots with no additional nitrogen and/or low level of nitrogen than higher nitrogen levels. Similarly higher tan spot severity in N deficient condition was observed by Fernandez et al (1998). In agreement with the results of Sharma and Duveiller (2004) and Chaurasia and Duveiller (2006) our results clearly suggested that higher dose of nitrogen had significant effect on reducing the disease and thereby increase the grain yield. This finding differs from the observation by Singh et al (1998) who reported higher disease infection with higher level of nitrogen.

Table 1. Means values for disease and agronomic variables at four level of nitrogen application and of six genotypes recorded in 2004 and 2005 wheat growing seasons at Tarahara, Sunsari, Nepal

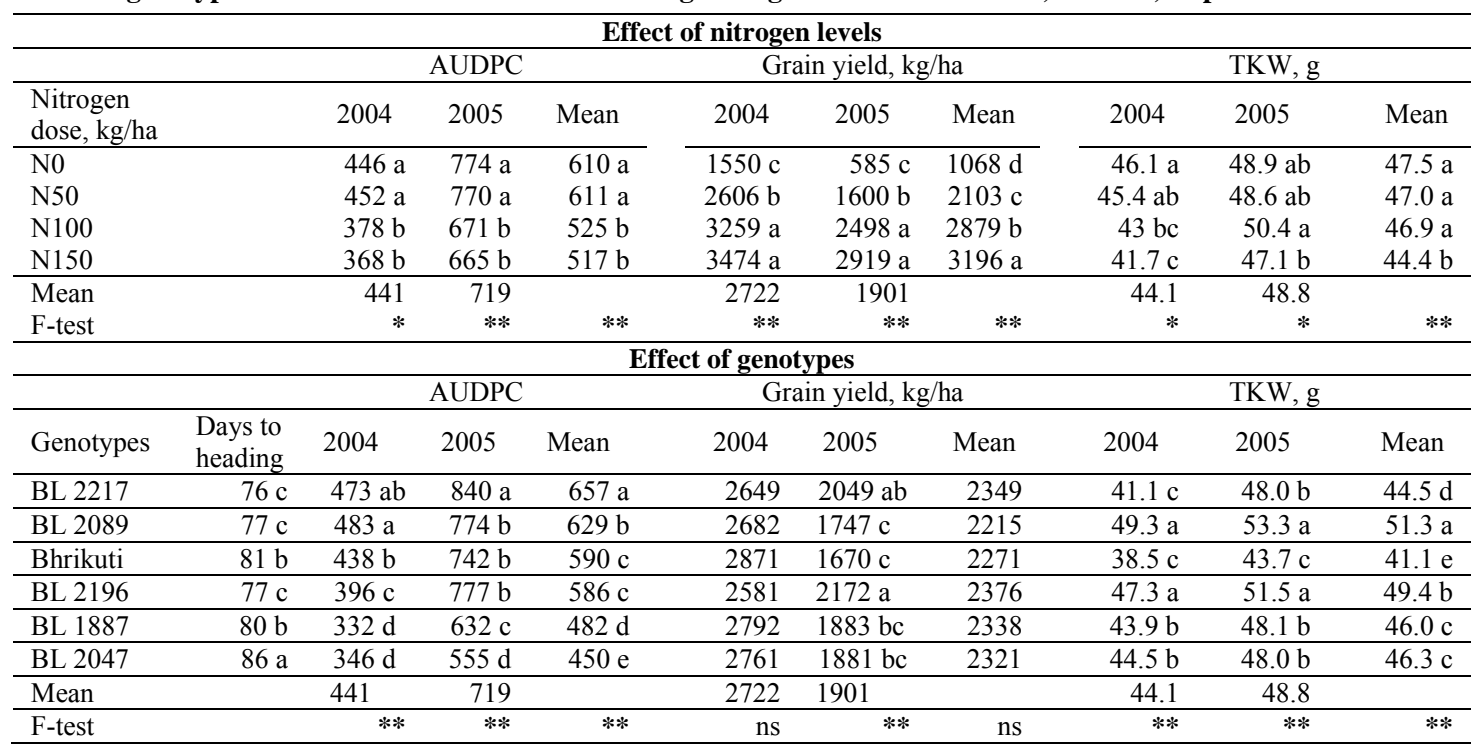

AUDPC, Area under disease progress curve, TKW= Thousand kernel weight. Means within a column followed by the same letter do not differ significantly based on least significant difference at $P=0.05$.

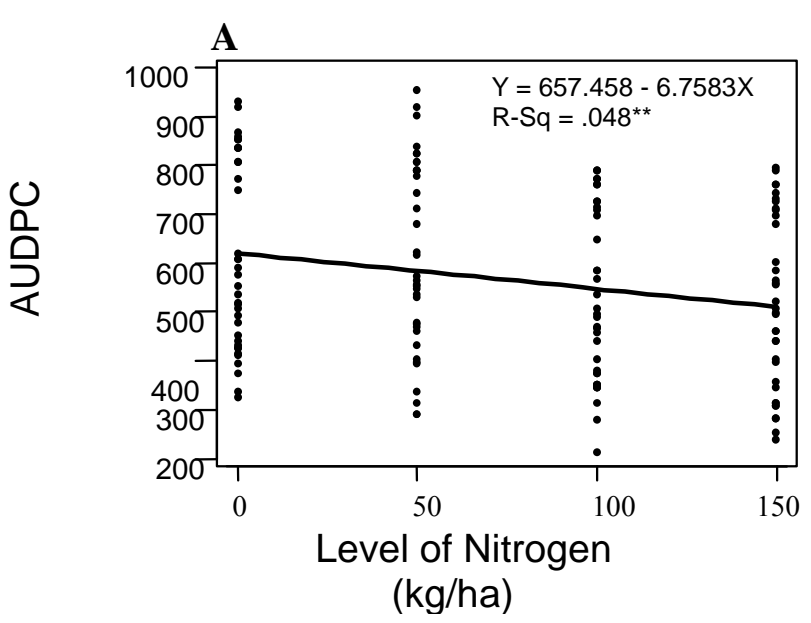

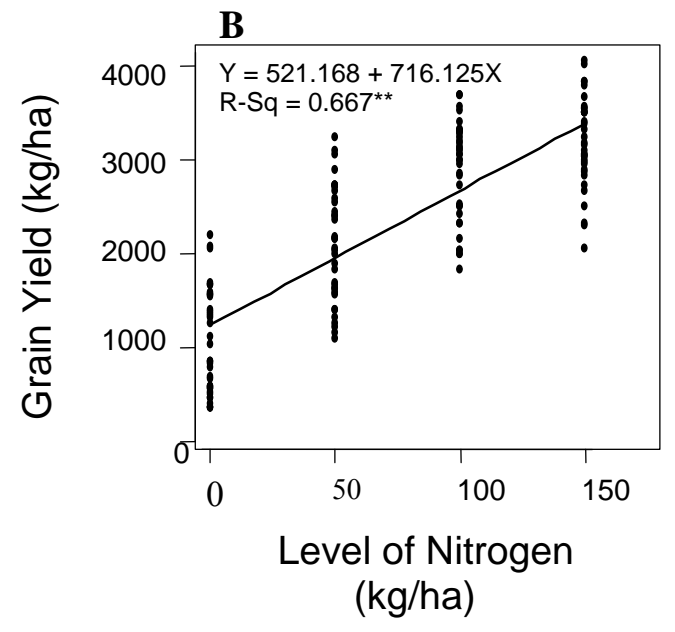


Nepal Agric. Res. J. Vol. 9, 2009

Figure 2. Regression lines indicating linear negative relation of area under disease progress curve (AUDPC; A) and linear positive relation of grain yield (kg/ha; B) over level of $\mathbf{N}$ in wheat grown at Sunsari, Nepal during 2004-05 and 200506 wheat growing seasons.

\section{Varietal performance}

Analysis of variance explicitly showed highly significant differences among genotypes $(\mathrm{P}<0.01)$ for AUDPC in both the years (Table 1). Interaction between the fertilizer dose and genotypes was insignificant and negative linear trend for AUDPC across nitrogen levels was observed in all the genotypes (Figure 3). Among the tested genotypes no resistance reaction to the disease was observed conforming previous observations of van Ginkel and Rajaram (1998). The six genotypes showed variations in level of resistance to the disease and agronomic traits. Such variation in disease level confirmed genetic differences among the genotypes. BL 2047 showed relatively higher disease resistance characterized by lower AUDPC value than others, and was followed by Gautam. Similarly, BL 2217 had the highest AUDPC value demonstrating the most susceptible to the disease among the tested genotypes (Table 1). The genotypes were significantly different in days to heading $(\mathrm{P}<0.01)$. Among the tested genotypes BL 2047 was relatively late and BL 2217 was early for days to heading (that foliar Table 1). This result suggested blight resistance in wheat genotypes was associated with maturity and confirmed the previous observations by Dubin et al (1998). They reported the best foliar blight resistant wheat genotypes in South Asia were late. A significant negative correlation between the days to heading and AUDPC was found by Mahto (1999). 


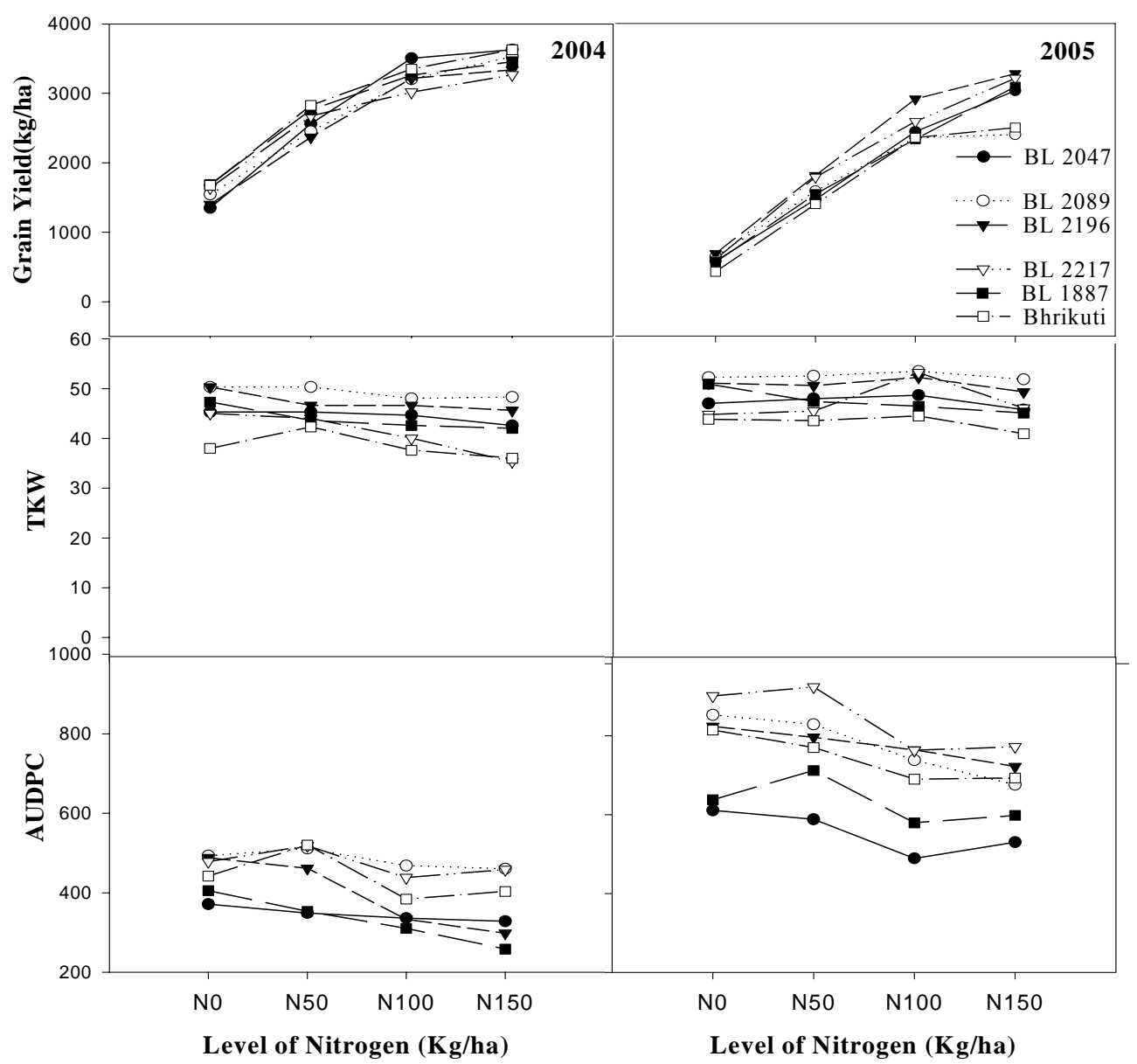

Figure 3. Changes in grain yield, thousand kernel weight (TKW), and area under disease progress curve (AUDPC) in six wheat genotypes across four level of nitrogen in the 2004 and 2005 wheat seasons at Tarahara, Sunsari, Nepal.

The wheat genotypes differed significantly only in the second year for grain yield (Table 1). In this year, genotype BL 2196 produced the highest yield $\left(2172 \mathrm{~kg} \mathrm{ha}^{-1}\right)$ which was followed by BL 2217 $\left(2049 \mathrm{~kg} \mathrm{ha}^{-1}\right)$. Despite having higher AUDPC value these genotypes produced higher grain yield suggesting they are tolerant to the disease. Among the tested genotypes thousand kernel weight was relatively high in BL 2089 followed by BL 2196. 


\section{CONCLUSION}

The findings of the study have implications for integrated management of foliar blight (HLB) disease of wheat. Nutrient management in field is very critical to minimize the disease severity. Crop without or with low dose of Nitrogenous fertilizer are vulnerable to severe foliar blight attack. Genotypes BL 2047 and BL 1887 showing relatively resistance, and BL 2196 having tolerance to the disease should be promoted. These three genotypes are potential and be crossed to combine resistance and tolerance to foliar blight along with high yielding progenies. By growing the selected cultivars with balanced dose of fertilizer@100:50:50 N: $\mathrm{P}_{2} \mathrm{O}_{5}: \mathrm{K}_{2} \mathrm{O} \mathrm{kg} \mathrm{ha}{ }^{-1}$, yield loss due to the disease in warm wheat growing climate could be minimized.

\section{ACKNOWLEDGEMENTS}

The authors are thankful to National Wheat Research Program, Bhairahawa for their support to arrange trial materials for this experiment. Mr AT Sherpa, Mrs BK Khatri and Mr G Magar are also acknowledged for their assistance in the trail management and data recording. Thank also goes to Mr SJ Bhusal for his constructive criticisms and valuable suggestions during experimentation period and manuscript preparation.

\section{REFERENCES}

Chaurasia PCP and E Duveiller. 2006. Management of leaf blight (Bipolaris sorokiniana) disease of wheat with cultural practices. Nepal Agric. Res. J. 7:63-69.

Dubin HJ and HP Bimb. 1991. Effect of soil and foliar treatments on yield and diseases of wheat in lowland of Nepal. In: Wheat in hot stressed environments: Irrigated, dry areas and rice-wheat systems (DA Saunders and GP Hettel, eds). CIMMYT, Mexico. Pp. 484-485.

Dubin HJ and HP Bimb. 1994. Studies of soil borne diseases and foliar blights of wheat at the National Wheat Research Experiment Station, Bhairahawa, Nepal. Wheat special report no 36. CIMMYT, Mexico.

Dubin HJ and S Rajaram. 1996. Breeding disease resistant wheats for tropical highlands and lowlands. Ann. Rev. Phytopathol. 34:503-526.

Dubin HJ, B Arun, SN Begam, M Bhatta, R Darai, LB Goel, AK Joshi, BM Khanna, PK Malakar, DR Pokhrel, MM Rahman, NK Shah, MA Shaheed, RC Sharma, AK Singh, RM Singh, RV Singh, M Vargas and PC Verma. 1998. Results of the South Asia Regional Helminthosporium leaf blight and yield experiments, 1993-94. In: Helminthosporium leaf blight of wheat: Spot blotch and tan spot (E Duveiller, HJ Dubin, J Reeves and A McNab, eds). CIMMYT, Mexico. Pp. 182-187.

Duveiller E and L Gilchrist. 1994. Production constraints due to Bipolaris sorokiniana in wheat: Current situation and future prospects. In: Wheat in hot stressed environments: Irrigated, dry areas and rice-wheat systems (DA Saunders and GP Hettel, eds). CIMMYT, Mexico. Pp. 343-352.

Duveiller E, YR Kandel, RC Sharma and SM Shrestha. 2005. Epidemiology of foliar 
blights (spot blotch and tan spot) of wheat in the plains bordering the Himalayas. Phytopathology 95:248-256.

Eyal Z, AL Scharen, JM Prescott and M van Ginkel. 1987. The septoria diseases of wheat: Concepts and methods of disease management. CIMMYT, Mexico.

Fernandez MR, RM Depauw, JM Clarke, RP Zentner and BG McConkey. 1998. Tan spot in western Canada. In: Helminthosporium leaf blight of wheat: Spot blotch and tan spot (E Duveiller, HJ Dubin, J Reeves and A McNab, eds). CIMMYT, Mexico. Pp. 73-79.

Gilbert J, SM Woods and A Tekauz. 1998. Incidence and severity of leaf spotting diseases of spring wheat in southern Minotoba. In: Helminthosporium leaf blight of wheat: Spot blotch and tan spot (E Duveiller, HJ Dubin, J Reeves and A McNab, eds). CIMMYT, Mexico. Pp. 333-338.

Krupinsky JM, AD Halvorson and AL Black. 1998. Leaf spot diseases of wheat in a conversation tillage study. In: Helminthosporium leaf blight of wheat: Spot blotch and tan spot (E Duveiller, HJ Dubin, J Reeves and A McNab, eds). CIMMYT, Mexico. Pp. 322-326.

Mahto BN. 1995. Wheat disease screening nurseries. In: Proceedings of the 1994-95 winter crop research workshop. NARC, Nepal. Pp. 289-307.

Mahto BN. 1999. Management of Helminthosporium leaf blight of wheat in Nepal. Indian Phytopathol. 52(4):408-413.

Naitao C and W Yousan. 1998. Incidence and current management of spot blotch of wheat in China. In: Helminthosporium leaf blight of wheat: Spot blotch and tan spot (E Duveiller, HJ Dubin, J Reeves and A McNab, eds). CIMMYT, Mexico. Pp. 119-125.

NWDP. 1976. Annual Report 1975/76. National Wheat Development Program (NWDP), Department of Agriculture, Ministry of Food, Agriculture and Irrigation, Nepal. Pp. 7581.

Rucksthul M. 1998. Population structure and epidemic of Bipolaris sorokiniana in ricewheat cropping pattern in Nepal. In: Helminthosporium leaf blight of wheat: Spot blotch and tan spot (E Duveiller, HJ Dubin, J Reeves and A McNab, eds). CIMMYT, Mexico. Pp. 88-106.

Saari EE and JM Prescott. 1975. A scale for appraising the foliar intensity of wheat diseases. Plant Dis Rep. 59:377-380.

Saari EE. 1998. Leaf blight disease and associated soil borne fungal pathogens of wheat in South and Southeast Asia. In: Helminthosporium leaf blight of wheat: Spot blotch and tan spot (E Duveiller, HJ Dubin, J Reeves and A McNab, eds). CIMMYT, Mexico. Pp. 37-51.

Saunders DA. 1988. Characterization of tropical wheat environments: Identification of production constraints and progress achieved in South and Southeast Asia. In: Wheat production constraints in tropical environments (AR Khatt, ed). CIMMYT, Mexico. Pp. 12-26.

Shaner G and Finney RE. 1977. The effect of nitrogen fertilization on the expression of slow-mildewing resistance in Knox wheat. Phytopathology 67:1051-1056. 
Sharma RC and E Duveiller. 2003. Effect of stress on Helminthosporium leaf blight in wheat. In: Proc. $4^{\text {th }}$ int. wheat tan spot and spot blotch workshop (JB Rasmussen TL Friesen and S Ali, eds). North Dakota State University, Fargo. Pp. 140-144.

Sharma RC and E Duveiller. 2004. Effect of Helminthosporium leaf blight on performance of timely seeded wheat under optimal and stress levels of soil fertility and moisture. Field Crop Research 89:205-218.

Shrestha KK, RD Timila, BN Mahto and HP Bimb. 1998. Disease incidence and yield loss due to foliar blight of wheat in Nepal. In: Helminthosporium leaf blight of wheat: Spot blotch and tan spot (E Duveiller, HJ Dubin, J Reeves and A McNab, eds). CIMMYT, Mexico. Pp. 67-72.

Singh RV, AK Singh, R Ahmad and SP Singh. 1998. Influence of agronomic practices on foliar blight and identification of alternate hosts in the rice-wheat cropping systems. In: Helminthosporium leaf blight of wheat: Spot blotch and tan spot (E Duveiller, HJ Dubin, J Reeves and A McNab, eds). CIMMYT, Mexico. Pp. 346-348.

van Ginkel M and S Rajaram. 1998. Breeding for resistance to spot blotch in wheat: Global prospective. In: Helminthosporium leaf blight of wheat: Spot blotch and tan spot (E Duveiller, HJ Dubin, J Reeves and A McNab, eds). CIMMYT, Mexico. Pp. 162-169. 